\title{
Findings of the midterm review of the implementation of the global health sector strategy and regional action plan for viral hepatitis
}

Citation: Findings of the midterm review of the implementation of the global health sector strategy and regional action plan for viral hepatitis. East Mediterr Health J. 2020;26(4):487-488 https://doi.org/10.26719/2020.26.4.487

Copyright @ W World Health Organization (WHO) 2020. Open Access. Some rights reserved. This work is available under the CC BY-NC-SA 3.0 IGO license (https://creativecommons.org/licenses/by-nc-sa/3.o/igo).

\section{Introduction}

During May 2016, the World Health Assembly endorsed the World Health Organization (WHO) global health sector strategy on viral hepatitis 2016-2021 (1), which aims to inspire countries to eliminate viral hepatitis as a public health threat by 2030 , reducing new infections by $90 \%$ and mortality by $65 \%$ (1). Accordingly, the WHO Eastern Mediterranean Region developed the regional action plan for the implementation of the global health sector strategy on viral hepatitis 2017-2021 (2), with a vision, goal and targets aligned with those of the global strategy. The purpose of the regional action plan is to provide a roadmap and priority actions to achieve an Eastern Mediterranean Region free of new hepatitis infections and where people living with chronic hepatitis have access to affordable and effective prevention, treatment and care (2).

Between September and December 2019, a midterm review of the implementation of the global health sector strategy and regional action plan took place, to assess the response to viral hepatitis at the regional and national levels. Following this, the WHO Regional Office for the Eastern Mediterranean (WHO/EMRO) organized a regional consultation on the findings of the midterm review in Lahore, Pakistan, 3-5 December 2019 (3). The consultation was attended by participants from countries of the Region as well as representatives from global partner and civil society organizations, and staff from WHO.

\section{The objectives of the consultation were to:}

- review and validate the findings of the midterm review of the implementation of the global health sector strategy and the regional action plan for viral hepatitis;

- identify impediments to progress towards national, regional and global targets, as well as identifying challenges and sharing best practices and lessons learned; and

- develop a roadmap for accelerated action towards achieving the 2021 targets and sustaining action towards hepatitis elimination by 2030 .

\section{Summary of discussions}

Participants reviewed the burden of viral hepatitis in the Region by country, as well as progress towards the global elimination targets and the milestones of the regional action plan. Gaps were identified including the need to strengthen key interventions, such as hepatitis $B$ birth dose, harm reduction and scaling up testing and treatment for both hepatitis B and C infection. Egypt's experience with hepatitis elimination was discussed, highlighting the country's efforts from the establishment of a national committee for viral hepatitis in 2006 up to the recent mass campaign to screen 60 million Egyptians and treat more than 3.5 million for hepatitis $C$ infection (4).

\section{Recommendations}

\section{To WHO}

- Providing technical support to Member States for policy dialogue and hepatitis response, including development of norms and standards, price negotiation, advocacy and resource mobilization.

- Exchanging best practices in health information and hepatitis response, including governance and community actions, as well as access to testing and treatment.

\section{To Member States}

- Designating focal points for national and subnational coordination of hepatitis response, as well as technical advisory groups with clear terms of reference to assist in identifying data sources and the review of strategies.

- Developing centralized national databases for hepatitis testing and treatment that include both the private and public sectors.

- Standardizing tools for hepatitis screening and treatment that are linked to the surveillance systems.

- Scaling up hepatitis B virus testing for pregnant women and 3-dose vaccination for infants.

- Developing national hepatitis guidelines, testing algorithms, and enhancing laboratory quality.

- Ensuring that hepatitis services are covered within health insurance schemes.

\footnotetext{
This report is based on the Summary Report on the Consultation of findings of the midterm review of the implementation of the global health sector strategy and regional action plan for viral hepatitis, 3-5 December 2019, Lahore, Pakistan (http://applications.emro.who.int/docs/EMSTD205E. pdf?ua =1).
} 


\section{References}

1. World Health Organization. Global health sector strategy on viral hepatitis 2016-2021. Geneva: World Health Organization; 2016 (https://www.who.int/hepatitis/strategy2016-2021/ghss-hep/en/).

2. World Health Organization Regional Office for the Eastern Mediterranean (WHO/EMRO). Regional action plan for the implementation of the global health sector strategy on viral hepatitis 2017-2021. Cairo: WHO/EMRO; 2017 (https://apps.who.int/iris/ handle/10665/258729).

3. World Health Organization Regional Office for the Eastern Mediterranean (WHO/EMRO). Consultation on findings of the midterm review of the implementation of the global health sector strategy and regional action plan for viral hepatitis. Cairo: WHO/ EMRO; 2020 (http://applications.emro.who.int/docs/EMSTD205E.pdf?ua=1).

4. The World Bank. Eliminating Hepatitis C from Egypt: 2017 Update on current trends and policy recommendations. Washington DC: The World Bank; 2017 (http://documents.worldbank.org/curated/en/164381517333701631/pdf/123068-WP-P157533-PUBLICEliminating-Hepatitis-C-from-Egypt-2017-Update.pdf). 